\title{
Book, bread and monument; continuity and change through ethnic memory and beyond
}

Aleksandra Ålund

The self-archived postprint version of this journal article is available at Linköping University Institutional Repository (DiVA):

http:/ / urn.kb.se/ resolve?urn=urn:nbn:se:liu:diva-45195

N.B.: When citing this work, cite the original publication.

This is an electronic version of an article published in:

Ålund, A., (1997), Book, bread and monument; continuity and change through ethnic memory and beyond, Innovation : the European J ournal of Social Sciences, 10(2), 145-160.

https:// doi.org/ 10.1080/ 13511610.1997.9968520

Original publication available at:

https:// doi.org/ 10.1080/ 13511610.1997.9968520

Copyright: Taylor \& Francis

http://taylorandfrancis.com/journals/ 


\title{
Book, Bread and Monument. Continuity and Change Through Ethnic Memory and Beyond
}

\author{
ALEKSANDRA ÅLUND
}

\begin{abstract}
The paper examines the meaning of ethnic memory as it finds expression in the life stories and identity formation of three young Swedish women of immigrant background. Their identity is formed within a field of tension between what is and what has been. Using the examples of different metaphors attached to the symbolic space of tradition, they seek to link time and space and thus fragments of migrants'splintered life. In relating the past to the present and its antagonisms to those of the present, all three girls demonstrate an ability to re-interpret and to translate tradition into present experience. This, the author maintains, can be understood as a creative capacity out of which a new kind of self-orientation is borm, and a new sense of home and belonging, come into being. In this way 'modem ethnic consciousness' takes form as a reflexive linkages across space and time. A new order is created out of the disorder of dissolved continuity.
\end{abstract}

Youth in multiethnic environments live in close and constant contact with the intensive cultural multiplicity of daily life. Diverse cultural elements are mixed and crossed; new identities are created. Behind the individual life stories to be recounted later, a common pattern emerges. In large measure, the issue among young people of immigrant descent seems to be the effort to re-create and identify an original context, and to sustain a continuity between past and present which is closely related to the need to be rooted. The feeling of outsider identity, and the search for socio-cultural belonging, characterize in a high degree the identity-work carried out by youth in multicultural societies. A recurrent theme in their life stories is the attempt to 'travel home', and to make 'home from home', as Phil Cohen has put it (Cohen, 1991). Identity-work has often to do with seeking one's abode, and one's obvious belonging.

This interest in metaphors touching on home and on travelling home, and the significance ascribed to them, has attracted increasing attention in the research on ethnicity, identity and social relations in modern society (see, for example, Berman, 1983; Gilroy, 1987; Ålund, 1991; Cohen, 1991; Schierup, 1993). Scholars have come to stress that the revitalization of the past in the present-the re-connection to and re-creation of 'tradition'-is at bottom an innovation and 'invention' (Hobsbawm and Ranger, 1993), rather than something old and 'genuine'. In large measure it works, moreover, through the creation of symbols and the reinterpretation of history in terms of a myth. What might be called ethnic memory plays an important role in this context, not least when it comes to personal life projects and individual choices in varying life situations. Yet the manner in which ethnic memory links yesterday with today is neither immediate nor simple. The encounter with the past usually means wrestling with 'ghosts' in the midst of the present (Schierup and Ålund, 1987; Ålund, 1991) and confronting the confining impact of tradition. The latter finds expression in relations between the generations not least.

The conditions of life experienced by migrants are stamped in a high degree by the break from past environments. Often this leads to feelings of nostalgia. These are expres- 
sed as a rule through remembered images of house and home as once they were. What was left 'back there' tends to become idealized and frozen in a sort of longing's grip, and this is strengthened by the distance, uncertainty and insecurity of life. The world of the past that is so missed, and which is more or less 'imagined', becomes metaphorically reshaped, so as to be capable still of yielding a longed-for security. Immigrants are hesitant and uncertain at first, and not seldom isolated from the surrounding society. The importance of continuity-holding fast to the old-is altogether central here. The effort to keep family, ethnic group and community together in the new country is experienced as critical; in the long run, however, this is a project fraught with conflict. Tensions soon arise-on many levels and in different dimensions; indeed, this becomes clear as soon as integration into the society and culture of the new country has commenced.

The ambivalent status of 'immigrant youth'-their sojourn in a cultural land of twilight-affects their identity-work. Their often marginal position in the societal division of labour-and that of their parents as well-carries great significance for the character and role of their ethnic memory. Their parents' generation may become locked into a dream of the home and the land they have left-with a idealizing purport that leads easily not merely to contrastive but also to negative projections vis-ì-vis the surrounding society. What might be called 'ethno-romanticism' is not unusual, especially among the first generation. By re-connecting with old and new enmities in their home countries, such persons often acquire a degree of intolerance and rigidity, in the name of which boundaries are staked out and obstacles raised. Yet their children seek a life under the new conditions notwithstanding, a life crossing and exceeding the boundaries drawn up by their parentsthrough ethnic memory and beyond it.

Young people try to find a foothold in the social spaces of daily life. Their identity is formed-their choices, dreams and visions are developed-within a field of tension between what is and what has been. The role of 'tradition' in this context is complex; its expressions are both direct and indirect. The autobiography of Maxine Hong Kingston (Kingston, 1976) reflects this type of identity-work in an revealing way. She portrays herself as 'the woman warrior'. She describes her growth to adulthood as a war with the childhood ghosts that accompanied her immigrant parents and relatives to the USA. Her identity-work was influenced by the meaning of tradition, and by the way in which it was shaped and re-interpreted in the light of contemporary experiences, preferences, obstacles and opportunities. Marshall Berman too discusses the presence of the past in the present (Berman, 1983). He finds an illustration of 'modern ethnic consciousness', moreover, in Kingston's autobiography. For Berman, modern ethnic consciousness takes the form of reflexive linkages across space and time. As ethnic memory builds new meaning by linking the old and the new, a new order is created out of the disorder of dissolved continuity. An identity is forged from symbolic assets; a new home, and a new sense of being at home, come into being. Out of the break with tradition a new kind of self-orientation is born, and a new rootedness in time and space. I shall return at the end of this essay-when considering Boelhower's discussion of identity-work under multicultural conditions-to the interplay between ethnic memory and identity-work (Boelhower, 1989).

Before this, however, three young women will have the opportunity to speak. All the complexities of modern identity-work find expression in their stories. As young women and as members of ethnic minorities, they confront a number of common ambiguities. They relate themselves consciously to the past, they seek links across time and space, and they are actively involved in the social and cultural conflicts attending their efforts to find their way home. 'Minorization' (Rath, 1990) and marginalization result in a series of tensions and conflicts. The combination of ethnicity, gender and youth renders such conflicts particularly marked and charged (McRobbie, 1994). We see this in the life stories that 
follow. The task, for these young women, is to reconcile the fragments of a splintered life. Above all, however, it is a question of breaking with barriers and fossilized rules-cultural, social, generational and sexual-in order that the field in which they may develop their identity as women can be widened, and the meaning of equality and individual freedomhitherto restricted - can be broadened.

\section{Hanna, the Book and a life of her own}

Hanna, a small young woman of 20 years, is dressed in tight-fitting jeans. She is half enveloped in a sea of curly long black hair. Sitting upright before me, she speaks of the Assyrian culture with an intensity which rises as her eyes-already black to begin withdilate even more. Hanna's actual name means White Stone.

The White Stone begins her story with memories of the Turkish-Assyrian countryside. When she was very small, she had watched over the goats belonging to her family. Today she finds, as she seeks her own way 'home' in Swedish society, that her life and identitywork are affected by flock-behaviour of another kind. The landscape through which her cultural journey takes her seems to consist, in large measure, of a terrain which is more or less difficult to penetrate.

"Once my parents lived in a house in another country. But neither the house nor the country are theirs any longer." Many immigrants begin their stories in roughly this way. The 'house' has a symbolic significance as something in which one is rooted and feels at home. The concept of the 'house' and its significance are important for relations between the generations, for continuity, and for conflicts and gaps as well. In the beginning, then, there was house and home. If these are to achieve their rightful importance, they must be seen again, and related to the time following emigration. Hanna explains:

I was there last summer, in Turkey, and I saw my house. But is it mine? Kurds can take it. Turks too. You don't have 'paper' [proof of ownership] for property. And no one demands 'paper' from anyone taking it over. I can't be certain it's mine. Land, house and country are temporary and uncertain 'properties'.

Assyrians are a mixture of several ethnic groups that were dispersed after the fall of the Assyrian realm. The roots of the ethnic identity are mysterious, and stretch back 2000 years in time. Through their Christian church, their holy texts and their common language, Assyrians have become a people in the course of the centuries. They lack, however, a state of their own in the Middle East. There is no homeland. The holy Book (the Assyrian bible, the holy texts) is the only thing providing a firm and fast connection with their origins. "This is why we hold by the church books so strongly-as a piece of fixed history."

The Book is a charged phenomenon in Hanna's life. Her parents and other Assyrians in Sweden hold fast to the Book and its history in a way that makes things problematic. Hanna is troubled that, as she puts it, "it seems easier to demonstrate one's cultural affiliation in a superficial than in a deep way". For a young woman like Hanna, it is complicated and difficult to experience her cultural affiliation as valuable and important, while at the same time considering its "surface culture"-as Hanna calls it-to be instrumental, oppressive and even exclusive. Hanna oscillates between, on the one hand, a critical attitude towards her ethnic group-many of whose members question whether she is a 'real' Assyrian - and, on the other, an extreme demonstration of her ethnic identity: "I've ended up in the worst position: I've become a nationalist, and I keep Assyrian ways more strictly than most. But they don't see me as a real Assyrian." Maybe it is exactly because she has come to defend tradition, after a fashion, that she has also become a threat to it.

"The 'real' Assyrians dress like Assyrians in order to show their identity. But I think 
like an Assyrian", she says. Hanna, who has studied, lays stress on the 'true' Assyrian roots and meanings. She twists and turns them in discussions with other Assyrians, and is met with suspicion and doubt. As a young woman, Hanna challenges much of what in the 'surface culture' of the adult world has become 'tradition.' In wishing to clarify and to question, she breaks with this 'tradition.' Her reflexive way of thinking, and the manner in which this is received, illustrate an ambivalence that often arises from transcultural encounters, especially when such encounters are expansively outward-oriented and implicated in creative development processes. On the one hand, cultural elements having to do with ethnicity are revitalized. On the other, this very revitalization explodes the 'tradition' from within. For Hanna, the difficult struggle to find her own life means making her way forward in a highly sensitive intersection between adaptation and liberation, possibilities and limits.

Hanna says she is troubled by the decline of tradition, which at first glance seems surprising. This is not exactly what one expects to hear from a young woman known among Assyrians in Stockholm for being an up-to-date and successful student.

The decline of tradition means that good customs are getting weaker and bad ones stronger. Marrying the young people off seems more important than what one has taught them. [Hanna thinks that] they [the older generation] hold on hard, in the wrong way, and they haven't really understood that they're in Sweden.

The old ways are important for the survival of the people and the culture. Since there's no land or country, the church books must furnish our identity. The language wouldn't survive without the church. It would be there in the church books. But it couldn't be changed through a living literary language.

Hanna thinks the spoken Assyrian language has changed and become poorer, as it has lost its living context and its continuity with origins.

The language has lived for hundreds of years as a spoken language. Now, I believe, it can't survive any longer. The children are forgetting. They speak Swedish through Assyrian, and the converse too, but in the wrong word order. Swedish is the opposite of Assyrian when it comes to word order, and it becomes like a mental shadow. They think in Swedish and talk in Assyrian.

Since the holy texts can only connect with a petrified language, Hanna fears the Assyrians will entrench themselves behind a culture that lacks depth and can therefore only oppress behind an empty maintenance of relics in which, as Hanna puts it, "the Book just becomes a collection of old paper".

Throughout our conversation, Hanna relates the Swedish to the Assyrian and viceversa. It is her way of creating meaning, of assigning things their significance. She came to Sweden when she was six years old, and has lived here ever since.

Without Sweden I would never have been educated, or been able to know so much or to find myself. In Turkey I wouldn't have cared about Assyrian things. There I would have lived like everyone else. But here I have become myself.

Becoming herself means, for Hanna, 'wondering, testing and knowing'. She sees her life in Sweden as a kind of liberation in the struggle for herself. But this liberation is accompanied by much thinking and reflecting, and by responsibility and concern.

In Turkey I wouldn't feel such responsibility and concern. Here in Sweden there are many opportunities, and I demand my right to become myself, with all that that means. In Turkey, others would take the responsibility, not me. 
Living 'spontaneously' and 'traditionally', without questioning, without knowing what different things mean, is nothing for Hanna. She must wrestle with the 'ghosts' of tradition, which must be named, renamed, and named anew if necessary (Ålund, 1991).

For Hanna, the encounter with Swedish ways has been a challenge and a leap in development, and it has spurred her interest in Assyrian cultural identity. Everyone-her school, her priest, her mother - had talked about Assyrian culture, but 'without explaining'. When it comes to the older generation, Hanna explains, the contrasts with Swedish ways-both real and exaggerated-have been the important element. The older members of the community have tended to entrench themselves behind the preservation of ritual. This has resulted in conflicts, such as that between Hanna and her immediate environment about the nature of 'real' Assyrian culture. The encounter with Swedish ways has given rise to alternative ways of understanding and behaving - both between and within generations.

"The others can't read and write our language. My education means I must help the others, so that they too can understand how they are Assyrians." When it comes to the keeping of Assyrian ways, the situation in Sweden differs from that in Turkey. She thinks the older generation in Sweden persists in a defensive strategy which is 'old-fashioned' and confining. 'In Sweden one need not, as earlier, defend one's life-using the culture as a shield-against a hostile world.' But the older generation still feels threatened.

They keep their children away from Swedish friends. Their world is authoritarian and hierarchical. Children and parents can't talk with each other in a reciprocal fashion. Everything is decided from above and down.

And since "they are still living in Turkey", Hanna says, parents do not take responsibility for their children. This "lack of responsibility" shows how the heavy bonds-which may once have been necessary for surviving and holding together-are no longer justified. To the extent such bonds are maintained just in order to keep contact with the past, Hanna believes that they amount in fact to a "break with the present". She seeks a dialogue-one marked by respect for differing views-within and between generations.

"I don't mean they should forget about food or about weddings. [But] you don't do your daughter a favour by marrying her off too early." Hanna fears she will be forced to marry 'too early', in order to demonstrate that, despite her education, she has not become Swedicized. She says this by indirection, when talking about general problems, and without stressing the personal. The same is true when she describes strained relations with the older generation.

I accept the respect for my father, my mother, and the older generation. I can't discuss my views of right and wrong with my father. But if I hadn't been able to talk with my mother either, than I wouldn't have become so open. And yet my mother is illiterate.

She speaks with sensitivity and respect about her parents, and in a manner suggesting that the roles are reversed. It is Hanna who takes the adult responsibility. She appreciates her parents. They take care of their children, and give them love in the only way they can. One must have patience, in Hanna's view. They must be given time. They must be respected if a dialogue is to be possible, she says.

To become a 'real' Assyrian woman, Hanna would have to marry early.

In that case I'd become like everybody else. Those who've married early and had kids are considered Assyrian - wholly and completely. Just because they've done that. In fact, however, they disappear. And though I know more than most, I'm still not considered the real thing. But what am I then? Even so I'm the real thing more than they are. 
Hanna strives to be more the real Assyrian than anybody else, in order to become herself. She reads the Book and translates it into the meanings of her own life. The road back to roots gives tradition a new content for Hanna, bringing her into conflict with a tradition which she, as a young person and a woman, is not supposed to question. Immigrant youth living in multiethnic environments have an especially pronounced need for active roots; this entails a need to connect and to change, and first and foremost to name. The demand to be able to participate in one's own history is therefore fundamental for how 'modern ethnic consciousness' is formed (Berman, 1983). Hanna can only escape the conflict with ingrained tradition by developing some sort of synthesis. In this, her cultural odyssey and identity-work are typical of modern ethnic consciousness.

There are no other books than the holy texts, says Hanna. We must therefore hold on to them - as a piece of fixed history. The Book symbolizes the ethnic identity, which is otherwise in danger of dissolving. The words in the Book have become an obsession for Hanna. Her mother has not been able to answer her questions about the words in the Book. Hanna says she must know in order to be able to take a position. The natural thing, she feels, would have been if her mother had been able to answer. In that case the words would have acquired a personal meaning. But if one gets no answers, how can one know what the meaning is? She searches for the words, and for confidence in her parents, family and ethnic community. For history must be translated and anchored, personally and individually, and related to the meanings in one's own life. Hanna is discovering that a common language is lacking. She realizes that, when she reflects on the history and takes possession of it-when she anchors the words in her own reality-she is breaking loose from the emptiness of the ingrained tradition. This yields concern and a sense of responsibility. The result is a sort of synthesis.

I want my younger siblings to grow up without feeling divided or being forced into paralysing choices. That's why I'm needed at home. They must become both Assyrians and Swedes. If they don't learn Assyrian, they won't learn Swedish either.

The content of this statement is more than just linguistic. Hanna seems to want here to stress how important it is to learn to be oneself, to respect oneself, and to develop further. It is first when one disposes, culturally speaking, over oneself that one can escape a compulsive division and a denial of one's true multicultural self.

The past is the history as it was experienced. For Hanna, a central figure in this history was her paternal grandmother.

I've always thought it was interesting to hear about how they lived and thought, over and over again. The last time I was in Turkey I was shocked-when I realized how my grandmother lived. Poverty-stricken. With an outhouse. And everybody drinks from the same ladle. I had forgotten about that since coming to Sweden. When grandma came to Sweden she was shocked - when she saw how we lived. I dare say she thought we had lost the rules and that we lived an ungoverned life.

Hanna wishes to continue her studies and to get involved in questions of development aid, the environment, international politics, and the rights of minority peoples. She wants "to have an impact on the unequal development in the world". Perhaps the common ladle will acquire a new meaning and significance thereby.

\section{Leana, Bread and Community}

For Leana too, her paternal grandmother is the most important person in the family. Leana's roots are in the Armenian diaspora. Her grandmother's tales loom large in the memories of her childhood. 
Grandma has told me stories since I was born. She makes things up. The same stories with new events, over and over again. She adds new parts all the time. It's about a mamma dog or a mamma goat who's looking for her young one. Different complications get added. The young one is missing. The mother gets into a big eggplant and rolls herself along in it, searching for her baby. She asks the other animals if they've seen her young one. They all answer that they'll show her the way in return for a piece of her eggplant. But they're lying. They don't know where her baby is; they just want her food. Grandma comes up with various animals, and they all say the same thing - 'if I get a piece'- though in different ways. After awhile there's not much left of the eggplant. At last the mother meets a crow who says to her: 'You're stupid to trust others. Your baby is sitting in the back of the garden and waiting for you'.

The stories are about poverty, threat, suspicion of 'others', and fear of losing one's property and each other. They also tell the diaspora tale of dispersion and re-union. "Grandma wanted to teach me not to trust everyone, and not to be easily deceived", Leana says. The stories also tell of a mythological community and the necessity of trusting to one's own. "This I have learned ...", Leana says, "... that we are all Armenians, wherever it is we come from". She continues:

I must think in this way. When I was younger I wondered if it had to be so. When I got older, though, I realized it was right-what the older people said-and that it was so'.

Does Leana take her ethnic 'particularity' as something given and self-evident? Or is that just on the level of rhetoric? Why did Leana not retain her wonder and her doubt? I ask Leana what she meant when she said that the older ones were 'right'. She stresses that Armenian history is important in this context.

When there was war between the Armenians and the Turks, members of my family were forced to flee, and our kin were divided. But, we have always kept our culture and our language.

What kind of culture? I ask.

The history of everything concerning us. Christianity (Orthodox), our language in writing and speech, the fact that we've never adopted the Roman alphabet. Our pride, that is to say. This is our culture which we maintain - through our parents and our home language.

I continue by asking what, for Leana, is the Armenian. She answers by enumerating Christian holidays and rituals. She particularly stresses the importance of bread, which stands for life's necessities, and its distribution. The afflictions of Armenian history have demanded solidarity among kin and ethnic group, especially when the outer world was thought to be hostile. Sharing the common bread, as expressed in rituals of various kinds, has brought the group together, and served as a symbol of unity within and of demarcation without.

The Armenian is so much. I don't really know. Religious customs. Easter. Wine that you drink in the right way. Most of all, it's the piece of bread remaining in the bowl after all have drunk their share.

I ask what is so special about the wine and the bread.

All Christians have them. The piece of bread is special. The bread means family 
and kin collected. Grandmother died two months ago. I discovered then how much relatives mean for each other. In sorrow. Everyone took part, came to the funeral, or made contact. We were a family.

Kin and people stand close to each other: Leana thinks the Armenians should gather again, now that Armenia has become an independent state.

The country needs help. Those who are divided need to be gathered. A country of our own. Finally. We in the Armenian youth league learn about the history of our people. We're going to Armenia in the summer to help out. It's mostly guys and older people. They know more than we do. But girls and youth are coming too.

Leana does not remember much about the Turkish Armenia she left as a child. Now she visits the new independent republic of Armenia yearly, in order to acquaint herself with Armenian ways and develop her Armenian identity. 'But ..., she comments, 'they take you around and show you just the good things, not the entire reality?

Leana, now seventeen years of age, came to Sweden when she was four, as one of three children in a large group of relatives who emigrated from Turkey. Leana goes to high school. She plans to be a hair-stylist and to open a salon of her own. Her family resembles any typical small Swedish family. Her father has a little kiosk, and her mother works at a supermarket. Leana likes her Stockholm suburb; "I feel at home here", she says. As far as Swedish Armenians are concerned, she takes the view that "those who are divided need to be united". To be divided means, for Leana, to be off on one's own. She thinks division should be counteracted on all levels.

If you don't socialize with Swedes, you don't learn the language. Those who don't learn Swedish are the ones who only associate with members of their own group. I've chosen to socialise with Swedes as much as with everyone else. We shouldn't be split up into small groups. In that case there would be trouble here.

Being divided has several dimensions, and it crosscuts the distinction between the Armenian and the Swedish. Seemingly paradoxically, Leana thinks that keeping Armenian ways in an internally well-integrated fashion makes for division, while connecting to Swedish ways means counteracting division. We are in Sweden now, and Armenians in different countries have become different kinds of Armenians. A relative from far away attending her grandmother's funeral commented that we have become like Swedes. Leana continues:

We mix Swedish words into our speech, and we are no longer as once we were. The others have kept more to Armenian ways. We lead two different lives, but we're very fond of each other.

"What has Sweden meant to your life?" I ask Leana. "I don't see my future here in Sweden", she says seriously, with a far-away look in her eyes. "I would like to go to Armenia". I wonder how her 'other life', the Swedish one, would feel if she lived in Armenia. "Would it be difficult?" I ask. "When I was there last it wasn't so free", she admits.

The styles of dress, friends and all that were not like here. I would miss that. But in the future-maybe in ten to twenty years-I would like to go there, perhaps. For there's something special there. My own country, where I'm not a foreigner. I can go to the store and speak my own language.

It is not so much Armenia that attracts her as a feeling, which she associates with Armenia, of a natural and self-evident belonging. The entire history of her people-diaspora, divi- 
sion, and attendant feelings of uncertainty, of being outside-all these are active within Leana's life, here and now.

What Leana calls the "two different lives" that Armenians lead become, for her, "two parallel lives", interwoven with each other. At the same time that the country is being built over there-more or less mythically-the immediate task is learning to feel at home here. "Why can't you see your future here in Sweden?" I wonder. "I didn't say that I can't. Maybe I can. But Armenia is important. I have learned that since I was little. I must think in that way." Existence in diaspora, or the feeling of dispersion and of being outside, underlines a striving to hold fast to the past, the mythological, as well as to the idea of returning or of meeting again. Leana too subordinates herself to the collective dream. But then she re-connects to herself and to her life in Sweden, and much of what she has earlier said appears to have been largely rhetorical.

They think in that way, as something obvious, through the older generation. The whole time they say: 'our language,' 'our culture,' 'our country'. If I should emigrate? What a word! I don't want to. What would I miss most? My friends here and the carnival.

Leana had socialized with Armenians before-through the Armenian association and suchlike. "Now other people are more important. Friends and schoolmates. You could never have such a life over there [in Armenia]." Today it is Stockholm that counts, as do the problems that young people in general wrestle with here and now. "We must travel a long way before anything happens. More activities should be arranged for young people here in the suburb."

We sit at a coffee-house, in the suburb centre. A collection of young men is standing outside. I have seen them standing there-like a street gang marking the small public scene-every time I have passed by. "I'm not bothered by them", says Leana. "It's fun that they're here. I've never had any trouble." Since beginning high school, Leana has made new friends from various places. Her world is growing.

Everyone is curious. My classmates ask where you come from. They want to know what it's like here in the suburb. They haven't dared come here, because they've heard so much about guys and about fighting. That if you so much as walk by the suburb the hooligans will come out and beat you up. I've said that's wrong, that bit about fighting. I've never seen it. Even if it can happen anywhere, I suppose.

Now Leana's friends dare to visit her suburb.

My buddy comes here every day. First I was at her place, but since coming here the first time she comes back all the time. She thinks the people here aren't as cold as in the city [Stockholm]. But she wouldn't come here if she didn't know someone [who lives] here.

"I'm an Armenian", Leana says. The identity is tied up with symbolism, with loyalty and community. In reality, however, she has incorporated the Armenian into her 'open world'. Like Hanna, Leana has developed an open ethnic identity. She mixes and crossfertilizes. This is evident, for example, when she talks about her future plans as a woman. The scenario she imagines is basically given; at the same time, however, the future is open.

Armenian men are faithful. Five per cent unfaithful. I'll marry an Armenian. We can marry others, but Armenian girls don't. We've learned that from our parents. It's hard marrying men with other customs and cultural practices. It should be Armenians. Yet it should also be as in Sweden, which means equality, friendship and money. 


\section{Aleksandra Ålund}

\section{Leana continues:}

To begin with, I'd want a husband who consults with me about everything. Hold myself to a man who isn't out in the evenings. It's important to have a good life, so money [is needed]. I would talk with the children about everything until they get older. Take it day by day until they can stand on their own two feet. Sometimes I miss the fact that my parents haven't had time to talk with me about life. I would take more time for the children.

Continuity and change, interwoven with each other, and all at the same time. In the shadow of, and yet beyond, the mystical setting of the saga and the community of bread, Leana's life and identity take form, tied both to the past and to reality here and now. As she tells me how she imagines her future, she looks out through the coffe-house window, carefully observing the group of young men, who are talking with some girls passing by. One of these young men, whom I recognize (and who is not an Armenian), waves to Leana. Then Leana walks out into her on-going life.

\section{Jelena, the Monument and transcultural belonging}

Jelena belongs to a cosmopolitan generation which has moved around the world. Now she has come into conflict with her own 'little world'. In the shadow of 'the great war,' her little world has erected a barrier of intolerance against all who threaten, as Jelena herself does, a mythological Serbian unity. Jelena's parents are Serbs. She herself lives together with a Kosovo-Albanian, and she is deeply attached to her boyfriend. Against the background of a disintegrating Yugoslavia, the majority of local Swedish Serbs in Jelena's suburb have adopted the Serbian motherland's view of Kosovo Albanians as a threat. By her love, Jelena has placed herself outside the inward-facing community and private microworld with its barriers of exclusion of her ethnic group. She has stood against slander in her community, and refused to abandon her boyfriend. With firm resolution she has made up her own mind, thus living up to the ideals she says she was raised by.

In an attempt to hold disintegrating values and worlds together; Jelena has been forced to endure an exhausting inner struggle. It is with great sorrow that she looks upon the dissolution of Yugoslavia, a country that she still sees as indivisible and as hers. And despite all personal experiences connected with persecuted relatives, who were expelled from other parts of ex-Yugoslavia, she nourishes no hatred towards those groups or individuals who have driven her relatives 'back' to 'their own.' She expresses despair, rather, that the values of equal worth and a common life on which Yugoslavia was built have been crushed. Her stories, replete with remembered images and heroic tales from the former Yugoslavia, show how she tries to connect her life here and now with the past. A certain monument, a memorial stone, has come to play a central role in how Jelena relates the one to the other. The message of this monument ties in closely, moreover, with Jelena's boundary-crossing view of the world and of life. She tells me:

In the middle of my grandfather's village, outside the People's Hall, there is a block of stone; a monument to all the dead heroes. I often went there when I was little, and I counted up all the dead-especially those with our family name. I asked grandpa who they were. The history interested me, for I took a personal pride in all 'my' heroes.

The heroes were mixed, like Jelena's family.

My father's family had come to the village from other parts of ex-Yugoslavia, when they fled from the violence of the Turks. They loaded everything they had 
on to an ox-cart. It is said that my ancestor declared that, 'Where my cart breaks down, there I will settle down.' When they passed the village the ox died. And so they stayed there.

Soon, Jelena's ancestors came to be among the village's own people. It is this which forms the core of her story.

We Serbs are also mixed. It is not 'just us'; many others are part of 'us' now too. I am descended from immigrants who, in various defensive wars, died together with the 'natives' for the common freedom. And now there on the memorial stone was their name. It was 'immigrants' who had become part of 'us', in other words, who were there on the monument now.

In her grandfather's village, people from all over-many of whom had fled-were mixed together. All became members of the village, the foreign and the new as surely as those whose forebears who had been there earlier.

I learned from grandpa to love your own, but to respect others. That was how I should act. If you love me, grandfather told me, then you should know that everybody is somebody's son or grandmother or mother. Everyone wants to be loved in the same way that you do. If you strike a person, his grandfather will be sadjust as I would be if somebody struck you.

Jelena feels that humanity-loving people and not states or borders-has been crushed with the war in Yugoslavia. She has a deeply rooted hope to live a life not determined by the boundaries of others. She became a pacifist early, and in this she was inspired by her grandfather.

"I feel shame over this horrible war. I don't understand why lunatics with guns drive people away from their homes." Jelena feels shame over this war between ethnically based factions, precisely because she does not herself identify as a member of a closed ethnic group. For those that refuse to conform to ethnically defined boundaries, this war is all but heroic. Instead it is a disgrace. One consequence of her attitude is that she sometimes is considered a traitor, someone who does not choose sides, and she ends up being rather alone. Jelena says it is hard to find people who think as she does. In her immediate environment, they spit on the other side. The division has become accentuated.

You can't bring them together in the same group. On my birthday it ended in chaos. I invited old friends, and quarrelling broke out. One of the guys told tasteless jokes about Bosnians. Think. These days. So tasteless. I argued and then I cried the whole night. Now what counts is where you're from, not how you are as a friend and a person. You're just viewed through your nationality, not your worth as a person. Everybody gets split up—nationally, internally, and according to ancestry and money.

Her social circle has shrunk. Jelena's best friend is a Bosnian Muslim whose boyfriend is a Serb. They too meet with the suspicion of their elders. Mixed relationships are not unusual among Yugo-Swedes, but such relationships are exposed now to severe strains. Jelena has decided, for her part, "that those who don't accept me and my boyfriend are no longer friends. And the number of friends grows smaller." As a result of these efforts to hold different worlds in her private life together, Jelena herself is thus forced, in a paradoxical way, to impose exclusions of a sort. Increasingly, her circle of friends consists of ethnically mixed couples.

It is confining to be pressured to select an identity in terms of clich such as Swedish, Serbian, Albanian, and so on. "I can't take a position that forces me to choose sides, to 
means identification with a group or tradition. On the other hand, the way an individual identifies with a group depends on the relation of the group to him/her and lies embedded in the individual's projections vis-à-vis the group.

Ethnic identity, and identification based on ethnic affiliation, are by no means self-evident. This may seen in the relations of tension between individual and ethnic group revealed in the stories of Hanna, Leana and Jelena. Their identity-work is complex. All three seck belonging in a multi-ethnic world; it is usually, moreover, a mixed and ramified affiliation that is in question. Yet such an ambition is not always self-evident for their parents, 'ethnic groups' or communities, which typically display petrified boundaries between different 'cultures' and ethnicities. In modern urban environments, however, new urban ethnicities and ethnic identities (Hall, 1992/94), which are multi-cultural, synchronic and hybrid in character (Gilroy, 1987; Hewitt, 1992) are emerging . Cultural elements are crossed with each other, and the close social relations of local life get interwoven with distant events and global contexts (Giddens, 1991).

As a rule, symbolic metaphors referring to home and belonging are hybrid, inasmuch as they refer to several different worlds. Such metaphors appeal to continuity and change simultaneously, i.e. to both the condition of being rooted and the process of seeking out something new (Ålund, 1993). They bind cultural expressions recovered from different generations. The varied experiences of migrants often mean that they enjoy differing prospects for seeing things from a range of perspectives, i.e., differing abilities to adopt a 'perspective' approach and to bind places and times with each other (cf. Boelhower, 1989, p. 158). Boelhower argues, citing T. S. Eliot, that the past can be seen as 'a heap of broken images'. Ethnic memory can be understood, seen in relation to this, as something that works in the present through recovery and re-interpretation (Boelhower, 1989, p. 162), i.e., through re-creation, reproduction, and re-use.

The need to re-connect backwards in time-with traditions and earlier generation-is common among migrants who have broken with their old cultural environment ( $\AA$ lund, 1978, 1993, 1994; Schierup and Ålund, 1987). Ethnicity is created actively (cf. Sollors, 1989), through construction, deconstruction, and reconstruction (Ålund, 1978; Boelhower, 1989). The dialectical movement from the one to the other may also provide an analytical framework for understanding the narrative and the tacit meaning hidden in the stories told by Hanna, Leana and Jelena. Through their ethnic memory they re-create; they work through and create anew. They recover, test, and relate to their lives here and now. Everything forms a single context in which the past and the present are bound reciprocally to each other. Continuity and change are played out simultaneously.

The mediation of intergenerational experience, as discussed by Boelhower (1989), belongs to the tradition of the 'three-stage'-synthesis in understanding the process of identity formation among migrants (cf. Ålund, 1978). The first stage involves re-visiting the 'catastrophic act topological dislocation' (Boelhower, 1989, p. 158), i.e. the abrupt break with an accustomed life setting: the journey away, the home lost, the new start. Home is constituted as a remembered home, a place to belong, it binds old and new affiliations. It expresses an ever-recurring need to keep the common anchoring in a shared past. Individual family members from different generations are all part of the common family, and relations are 'intra-cultural' and dense.

Then a kind of deconstruction takes place. Often it is tied to conflicts and strained relations between different generations. During this stage individuals examine how the metaphors, prototypes and cultural elements, stored in the ethnic memory, relate to real life conditions, here and now. The new country's customs penetrate the world of the migrants; this injects strains into relations between old and young, men and women, parents and children. The world beyond family and ethnic group intrudes. New contacts, perceptions and 
knowledge inspire individuals to question established interpretations of tradition's true meaning. Instability and discontinuity get the upper hand.

The third stage entails a reconciliation of sorts: continuity and change through reconstruction. Through a kind of ethnic semiotics, the cultural elements stored in the ethnic memory are given a new content. The tradition is reconstructed-reinterpreted and endowed with new meaning - both in terms of the ethnic memory and in terms of the conceptions associated with the current realities and needs inscribed in individual life projects. This entails moving back and forth between different cultural perspectives: it means proceeding from construction through deconstruction to reconstruction (cf. Ålund, 1978). Space and time are re-defined when cultural boundaries are broken. The mono-cultural is abandoned in favour of the multi-cultural. The ethnic comes to bind disparate life fragments through dialogue and dialogical production, rather than through repetition and monologue (cf. Boelhower, 1989).

Does this mean the specific and the ethnic wholly dissolve? Through new connections and dialogical reinterpretation, a 'poetics of continuity' (Boelhower, 1989, p. 174) is composed. Ethnic narratives appear within a radical breach between the 'tradition' and the 'self'. They bear within themselves a cultural history in which continuity is continuously reconstructed.

In the narratives, as we have seen in the cases of Hanna, Jelena and Leana, numerous encounters with the past are taking place. They are expressed through a kind of self inquiry, which speaks through heavily laden metaphors; the translated tradition is merging with experiences of ongoing life. By intersecting time and space as a source of recognition, by networking and by cultivating consciousness concerned with both old and new antagonisms, the past makes itself felt in the present. Intercultural encounters in time and space reflect struggles with the past's symbolic ghosts and roots, which may simultaneously lead to both reconciliation and emancipation. However, the symbolic 'wrestling with ghosts' of tradition-embedded in the formation of identity (Ålund, 1991; Ålund and Schierup, 1991)-bears new messages. In the condensed interplay between old and new antagonisms faced by ethnic minorities, novel insights are released and a more profound cmancipatory potential is submerged (Ålund, 1991, 1995). The dynamics of ethnic memory, the ability to connect the present with the past and its antagonism to the present, become actualized as a creative power to interrelate, to translate and to transcend.

Re-creation of the ethnic memory and new creation through reinterpretation become intertwined. These processes are critical for understanding the geneses and character of modern identity, for the developmental possibilities of the transcultural society and the necessity for such a society as well.

\section{References}

Ålund, A. (1978), Migration och sociala forändringsprocesser; Om samtida jugoslaviska arbetsmigranter [Migration and Processes of Social Change, About Contemporary Yugoslav Labour Migrants], Research Report No. 44, Department of Sociology, University of Umeå.

Ålund, A. (1991), 'Modern youth and transcultural identities', European foumal of Intercultural Studies, Vol. 2, pp. 49-63.

Ålund, A. (1993), 'Crossing boundaries, notes on transethnicity in modern puristic society', in Xenofobia and Exile; Rescue-43, Copenhagen, Munksgaard, pp. 149-161.

Ålund A. (1994), 'Etnicity and modernity, on tradition in modern cultural studies', in Rex, J. and Drury, B. (eds), Ettmic Mobilisation in a Multi-Cullural Europe, Aldershot, Avebury, pp. 57-69.

Ålund, A. (1995), 'Alterity in modernity', Acta Sociologica, Vol, 38, pp. 311-322. 
Ålund, A. and Schierup, G.-U. (1991), Paradoxes of Multiculturalism, Aldershot, Avebury. Berman, M. (1983), All That is Solid Melts into Air: The Experience of Modernity, London, Verso. Boelhower, W. (1989), 'Ethnic trilogies, a geneological and generational poetics', in Sollors, W. (ed.), The Invention of Ethnicity, New York/Oxford, Oxford University Press.

Cohen, P. (1991), 'The migration of identity', Unpublished manuscript, New Ethnicities Institute, Polytechnic of East London.

Ehn, B. (1990), 'The organisation of diversity: youth experiences in multi-ethnic Sweden,' paper for the Organisation of Diversity conference, Stockholm.

Giddens, A. (1991), Modernity and Self Identity, Oxford, Polity.

Gilroy, P. (1987), There Ain't no Black in the Union Jack, London, Hutchinson.

Hall, S. (1992/94), 'New ethnicities', in Donald, J. and Rattansi, A. (eds), Race, Culture and Difference, London, Sage.

Hewitt, R. (1992), 'Language, youth and the destabilisation of ethnicity', in Palmgren, et al. (eds), Ethnicity in Youth Cullure, Stockholm, Stockholm University of Stockholm, pp. 3743.

Hobsbawm, E. and Ranger, T. (1993), The Invention of Tradition, Cambridge, Cambridge University Press.

Jackson, P. (1989/1994), Maps of Meaning, London and New York, Routledge.

Kingston, M. H. (1976), The Woman Warrior: Memory of a Girlhood Among Ghosts, New York, Knopf.

Le Page, R. B. and Tabouret-Kelleur, A. (1985), Acts of Identity, Creole-Based Approach to Language and Ethnicity, Cambridge, Cambridge University Press.

Lundgren, E. (1992), 'The hand that strikes and comforts: gender construction in the field of tension encompassing body and symbol, stability and change', in Rethinking Change: Current Swedish Feminist Research, Stockholm, HSFR, pp. 131-158.

Lundgren, E. (1995), Feminist Theory and Violent Empiricism, Aldershot, Avebury.

McRobbie, A. (1994), Postmodemism and Popular Culture, London and New York, Routledge. Rath, J. (1990), 'The ideological representation of migrant workers in Europe; a matter of racialisation?', in Wrench, J. and Solomos, J. (eds.), Racism and Migration in Western Europe, Oxford/Providence, Berg.

Schierup, G.-U. (1993), Pa kulturens slagmark: Mindretal och st"rretal om Danmark, Esbjerg, Sydjysk Universitetsförlag.

Schierup, C.-U. and Ålund, A. (1987), Will They Still Be Dancing? Integration and Ethric Transformation among Yugoslav Immigrants in Scandinavia, Stockholm, Almqvist \& Wiksell.

Sollors, W. (ed.) (1989), The Invention of Ethnicity, New York andOxford, Oxford University Press.

Ziche, T and Stubenrauch, H. (1983), Plädoyer fur ungezwöhnliches Lemen: Ideen zur fugendsituation, Hamburg, Rohwohlt. 